AlEKSANDRA JASIELSKA

MARZENA BuCHNAT

Uniwersytet im. Adama Mickiewicza

w Poznaniu

\title{
DEFICYTY EMOCJONALNE MŁODYCH DOROSŁYCH WYCHOWANKÓW RODZIN ZASTĘPCZYCH
}

\begin{abstract}
AвSTRACT. Jasielska Aleksandra, Buchnat Marzena, Deficyty emocjonalne młodych dorostych wychowanków rodzin zastępczych [The Emotional Deficits of Young Foster Care Alumni]. Studia Edukacyjne nr 48, 2018, Poznań 2018, pp. 259-280. Adam Mickiewicz University Press. ISSN 1233-6688. DOI: 10.14746/ se.2018.48.17

The study was aimed to determine the role of attachment bond in emotional functioning in alexithymia and emotional processing in foster care alumni. The participants with experience of personal rejection - adult foster care alumni during the transition from foster care to adulthood $(\mathrm{N}=29)$ and persons without such experience $(\mathrm{N}=32)$ took part in the study. The Experiences in Close Relationships Scale, Toronto Alexithymia Scale and Emotional Processing Scale were used. Results present that insecure pattern of attachment occurs with alexithymia in ineffective emotional processing. We confront the results with the construct of emotion representations as the key to comprehend observed deficits in emotional functioning.
\end{abstract}

Key words: alexithymia, attachment theory, emotional processing, foster family, representation of emotion

\section{Wprowadzenie}

Teoria przywiązania Bowlby'ego ${ }^{1}$ głosi, że w pierwszych latach życia dziecka kształtuje się kluczowe dla funkcjonowania psychicznego przywiązanie pomiędzy nim a obiektem przywiązania, czyli najczęściej matką, oraz że funkcjonowanie systemu przywiązania służy procesowi regulacji emocjonalnej. Jakość relacji między dzieckiem a jego opiekunem skutkuje rozwojem

\footnotetext{
${ }^{1}$ J. Bowlby, Attachment and Loss. Loss: Sadness and Depression, vol. 3, Harmondsworth 1991.
} 
dwóch zasadniczych stylów przywiązania: bezpiecznego i pozabezpiecznego, w obrębie którego wyróżnia się kolejne style - ambiwalentny, unikający i zdezorganizowany ${ }^{2}$. Początkowo Bowlby ${ }^{3}$ podkreślał etiologiczne i behawioralne aspekty relacji przywiązaniowej, jednak później akcentował ważną rolę emocji w kształtowaniu się przywiązania

Żadnej innej formie zachowania nie towarzyszą tak silne uczucia, jak to jest w przypadku zachowania przywiązaniowego. Figury, do których jest ono kierowane są obdarzone miłością (są kochane), a ich pojawienie się jest związane z radością. Tak długo, jak dziecko znajduje się w niezagrożonej niczym bliskości z opiekunem, czuje się bezpieczne. Zagrożenie utratą tej bliskości wzbudza lęk, faktyczna utrata smutek, oba zdarzenia zaś wywołują złośćt.

Zasadnicze znaczenie $\mathrm{w}$ tej teorii przypisuje się posiadanym przez jednostkę kognitywno-afektywnym reprezentacjom obiektu przywiązania, ,ja“", relacji między nimi i otoczeniem. Reprezentacje te noszą nazwę „wewnętrznych modeli operacyjnych przywiązania" (WMO). WMO są subiektywne, ponieważ zawierają zapamiętane doświadczenie jednostki oraz interpretują dane z jej perspektywy. Strukturalnie stanowią część rozbudowanej sieci schematów zorganizowanych na różnych poziomach ogólności ${ }^{5}$. Ich funkcja polega na organizacji informacji dotyczących doświadczeń i uczuć związanych z przywiązaniem (zarówno w świadomości, jak i poza nią) i kierowaniem zachowaniem w nowych sytuacjach ${ }^{6}$.

Wzorzec przywiązania ukształtowany w dzieciństwie wpływa na jakość relacji w dalszym życiu oraz na sposób postrzegania siebie i świata społecznego ${ }^{7}$. Modyfikacja teorii przywiązania dla osób dorosłych zaowocowała wyłonieniem czterech stylów przywiązania zależnych od sposobu, w jaki osoba wartościuje siebie i innych ${ }^{8}$. Zaproponowano istnienie dwóch rodzajów WMO

${ }^{2}$ M. Czub, Wiek niemowlęcy. Jak rozpoznać potencjał dziecka? [w:] Psychologiczne portrety człowieka. Praktyczna psychologia rozwojowa, red. A.I. Brzezińska, Gdańsk 2005, s. 41-66.

${ }^{3}$ J. Bowlby, Attachment and Loss, vol. 1, Harmondsworth 1982.

${ }_{4}$ Tamże, s. 209.

${ }^{5}$ I. Bretherton, K.A. Munholland, Internal Working in Attachment Relationships. A Construct Revisited, [w:] Handbook of Attachment. Theory. Research and Clinical Applications, red. J. Cassidy, P.R. Shaver, New York - London 1999, s. 89-111.

${ }^{6}$ E. Waters, N.S. Weinfield, C.E. Hamilton, The Stability of Attachment Security from Infancy to Adolescence and Early Adulthood: General Discussion, Child Development, 2000, 71, 3, s. 703-706.

7 R.S. Edelstein i in., Individual differences in emotional memory: Adult attachment and long-term memory for child sexual abuse, Personality and Social Psychology Bulletin, 2005, 31, s. 1537-1548; C. Hazan, D. Zeifman, Pair Bonds as Attachments: Evaluating the Evidence, [w:] Handbook of Attachment. Theory, s. 336-354; A. Troisi i in., Insecure attachment and alexithymia in young men with mood symptoms, Journal of Nervous and Mental Disease, 2001, 189, s. 311-316.

${ }^{8}$ K. Bartholomew, L.M. Horowitz, Attachment Styles among Young Adults: A Test of a Four-Category Model, Journal of Personality and Social Psychology, 1991, 61, s. 226-244. 
- modelu siebie i wewnętrznego modelu innych. Każdy z nich został zdychotomizowany na pozytywny i negatywny. W efekcie powstały cztery dorosłe wzorce przywiązania: ufny (pozytywny obraz siebie i innych), zaabsorbowany (negatywny obraz siebie, pozytywny obraz innych), odrzucający (pozytywny obraz siebie, negatywny obraz innych) i lękowy (negatywny obraz siebie i innych).

Współcześnie teoria przywiązania wykorzystywana jest między innymi do wyjaśniania przebiegu procesu regulacji emocji. Sposób regulowania emocji zależy od wzorca przywiązania, rozumianego jako "usystematyzowany wzorzec przewidywań interpersonalnych, emocji i zachowań wynikających z uwewnętrznienia danej historii doświadczeń przywiązaniowych i z konsekwentnego korzystania $z$ danej strategii regulacji emocji"10. W bezpiecznym stylu przywiązania regulacja emocji ma charakter adaptacyjny i sprzyja celom jednostki. Natomiast, w pozabezpiecznych stylach przywiązania przebiega od hiperaktywacji, polegającej na nadmiernym angażowaniu energii mentalnej i czasu w monitorowanie i utrzymywanie bliskości z obiektem przywiązania, po deaktywację związaną z rozszczepieniem doświadczania i ekspresji afektu. Hiperaktywacja jest charakterystyczna dla osób o ambiwalentnym/ zaabsorbowanym stylu przywiązania. $Z$ kolei deaktywacja w różnej formie jest charakterystyczna dla unikającego i odrzucającego stylu przywiązania ${ }^{11}$.

Jakość relacji w okresie wczesnego dzieciństwa sprzyja nie tylko rozwojowi określonych stylów przywiązania, ale także jej nieodpowiednia forma, na przykład pod postacią braku bezpiecznych więzi, skutkuje między innymi pojawieniem się aleksytymii. Syndrom aleksytymii definiowany jest jako niezdolność do rozumienia lub identyfikowania emocji oraz ich nazywania i wyrażania, której towarzyszy operacyjny styl myślenia oraz uboga wyobraźnia $^{12}$. Zdaniem Krystala ${ }^{13}$, istotą rozwoju emocjonalnego jest przekształcenie

${ }^{9}$ Wyróżnione style odpowiadają klasycznym stylom: ufny - bezpiecznemu, zaabsorbowany - ambiwalentnemu, lękowy - unikającemu, odrzucający - zdezorganizowanemu za: K. Bartholomew, L.M. Horowitz, Attachment Styles among Young Adults, s. 226-244; por. K. Rajewska-Rynkowska, Schematy przywiązania do obiektu religijnego w kontekście aktywacji myśli o śmierci - niepublikowana praca doktorska, Poznań 2008 s. 25-27.

${ }_{10}$ M. Mikulincer, P.R. Shaver, D. Pereg, Attachment Theory and Affect Regulation: The Dynamics. Development. and Cognitive Consequences of Attachment-Related Strategies, Motivation and Emotion, 2003, 27, 2, s. 79.

${ }^{11}$ J.M. Fuendeling, Affect Regulation as a Stylistic Process within Adult Attachment, "Journal of Social and Personal Relationships" 1998, nr 15, 3, s. 291-322; por. K. Rajewska-Rynkowska, Schematy przywiązania do obiektu religijnego, s. 30-31.

12 A. Bilikiewicz, W. Strzyżewski, Psychiatria: podręcznik dla studentów medycyny, Warszawa 1992, s. 482; S. Kench, H.J. Irwin, Alexithymia and childhood family environment, Journal of Clinical Psychology, 2000, 5, s. 737-745; T. Maruszewski, E. Ścigała, Emocje - aleksytymia - poznanie, Poznań 1998.

${ }^{13}$ H. Krystal, Integration and self-healing: affect, trauma, alexithymia, New York 1988. 
niezróżnicowanego afektu w precyzyjnie zróżnicowane emocje ${ }^{14}$. Proces taki jest możliwy tylko w warunkach niezaburzonej relacji matki z dzieckiem, jak w przytoczonej teorii Bowlby'ego. Brak zaspokojenia dziecięcych potrzeb przez opiekuna prowadzi do zaburzeń rozwoju afektywnego pod postacią zablokowanego różnicowania i werbalizacji oraz desomatyzacji emocji. W konsekwencji, emocje są niezrozumiałe i stłumione, czego objawem może być aleksytymia ${ }^{15}$. Z kolei w paradygmacie poznawczym przywiązanie można traktować jako uwarunkowany biologicznie potencjał do tworzenia reprezentacji emocji, na bazie którego zostaje uruchomiona dalsza obróbka poznawcza. W tym ujęciu kluczową rolę w etiologii aleksytymii przypisuje się wadliwie ukształtowanym reprezentacjom emocji w okresie wczesnego dzieciństwa ${ }^{16}$ i zdeformowanym procesom kodowania doświadczeńn ${ }^{17}$.

$\mathrm{Z}$ kolei, w teoriach przetwarzania informacji uznaje się, że aleksytymia jest deficytem związanym $z$ odbiorem i wykorzystywaniem wiedzy emocjonalnej ${ }^{18}$. Efektywny proces emocjonalny opiera się na przejściach pomiędzy domenami reprezentacji emocji. Są to kolejno czynnik wywołujący, ocena bodźca, wtórna ocena znaczenia emocji, przygotowanie do odpowiedzi afektywnej i odpowiedź behawioralna. W ujęciu tym aleksytymia wynika z braku połączenia pomiędzy poszczególnymi domenami, w szczególności pomiędzy czynnikiem wywołującym a oceną lub oceną wtórną a odpowiedzią.

Także przetwarzanie emocjonalne ${ }^{19}$ wyjaśniane jest za pomocą złożonych, wielopoziomowych modeli poznawczo-emocjonalnych zawierających różne formy reprezentowania i typy kodowania emocji ${ }^{20} \mathrm{czy}$ połączenia pomiędzy swoistymi etapami procesu emocjonalnego ${ }^{21}$. Przetwarzanie emocjonalne to proces, dzięki któremu osoba absorbuje i osłabia emocjonalne pobudzenie związane z uprzednim wydarzeniem emocjonalnym, by nie zakłócało dal-

14 T. Maruszewski, E. Ścigała, Emocje - aleksytymia - poznanie, s. 155-162.

15 D. Płońska, A. Czernikiewicz, Aleksytymia - ciągle wiele pytań, cz. I - Definiowanie aleksytymii, Psychiatria, 2006, 3, s. 1-7.

16 G.J. Taylor, R.M. Bagby, J.D.A. Parker, The development and regulation of affect, [w:] Disorders of affect regulation; alexithymia in medical and psychiatric illness, red. G.J. Taylor, R.M. Bagby, J.D.A. Parker, Cambridge 1997, s. 24-25.

17 W. Bucci, The Need for a "Psychoanalytic Psychology" in the Cognitive Science Field, Psychoanalytic Psychology, 2000, 17, s. 203-224; T. Maruszewski, E. Ścigała, Emocje - aleksytymia - poznanie.

18 W. Frawley, R.N. Smith, A processing theory of alexithymia, Cognitive Systems Researc, 2001, 22, s. 189-206.

19 R. Baker i in., Development of an emotional processing scale, Journal of Psychosomatic Research 2007a, 62, s. 167-178.

${ }^{20}$ W. Bucci, The Need for a "Psychoanalytic Psychology, s. 203-224; tenże, The interplay of subsymbolic and symbolic processes in psychoanalytic treatment, "Psychoanalytic Dialogues" 2005, 15, 6, s. 855-873.

${ }^{21}$ W. Frawley, R.N. Smith, A processing theory of alexithymia, s. 189-206. 
szego doświadczania i zachowania ${ }^{22}$. W większości przypadków absorpcja zakłócenia emocjonalnego zachodzi w sposób bezproblemowy, jeśli jednak dzieje się inaczej pojawiają się przejawy niewystarczającego przetwarzania (np. nadmierna przerzutność uwagi, poirytowanie, obsesje, stany dysocjacyjne) ${ }^{23}$. Kontynuatorzy myśli Rachmana - R. Baker i jego współpracownicy ${ }^{24}$ kładą nacisk na intrapsychiczne mechanizmy, zaangażowane w przemianę bodźca w stan umysłu, w znaczenie psychologiczne i jego konsekwencje. Wskazują możliwe zakłócenia na poszczególnych etapach powstawania rekcji emocjonalnej - spostrzeżenia bodźca, oceny poznawczej i nadania znaczenia sytuacji, przeżycia emocjonalnego, gotowości do działania, zmiany somatycznej, ekspresji ${ }^{25}$. Ponadto, wskazują na charakterystyczne dla każdego etapu nieadaptacyjne strategie regulacji.

Wydarzeniom na wejściu mogą towarzyszyć strategie aktywnego unikania, szczególnie negatywnych wydarzeń emotogennych i związanych z nimi myśli. $\mathrm{Na}$ etapie doświadczania emocjonalnego występuje zubożenie pod postacią, na przykład, niezdolności do pełnego doświadczania emocji, to jest łączenia w przeżyciu wszystkich komponentów emocji: fizjologicznego, subiektywnodoświadczeniowego i poznawczego, trudności w identyfikacji i werbalizacji emocji oraz w odróżnianiu emocji od innych doznań fizycznych, czy błędnego określenia przyczyn emocji. Kiedy ograniczone jest doświadczanie emocji, pojawiają się symptomy nieprzetworzonych emocji pod postacią natrętnego i uporczywego ich przeżywania. Zarówno w przypadku doświadczania emocjonalnego, jak i ekspresji emocji trudności w przetwarzaniu emocjonalnym dotyczą z jednej strony niezdolności do kontroli uczuć - brak regulacji, a z drugiej strony nadmiernej kontroli doświadczenia i ekspresji - tłumienie związanej z negatywnym wartościowaniem emocji. Niezdolność do regulacji jest szczególnie widoczna wówczas, kiedy występują silne uczucia, a osoba reaguje nadmiernie, nie kontrolując ani swoich słów, ani działań. Skrajne tłumienie występuje w całkowitym nieujawnianiu emocji i braku spontaniczności.

Zaprezentowane deficyty w zakresie przetwarzania emocjonalnego można wskazać u osób manifestujących pozabezpieczne style przywiązania ${ }^{26}$. Na przykład, u osób o stylu unikającym można wskazać zachowania charakterystyczne dla strategii unikania i tłumienia. Osoby te odwracają uwagę

${ }^{22}$ S. Rachman, Emotional processing, Behaviour Research and Therapy, 1980, 18, s. 51.

${ }^{23}$ Tamże, s. 51-60.

${ }^{24}$ R. Baker i in., Emotional processing in panic, Behaviour Research and Therapy, 2004, 42, s. 127-128; tychże, Development of an emotional processing scale, Journal of Psychosomatic Research, 2007, 62, s. 167-178; por. D. Górska, A. Jasielska, Konceptualizacja przetwarzania emocjonalnego i jego pomiar - badania nad polska wersją Skali Przetwarzania Emocjonalnego Bakera i wspótpracowników, Studia Psychologiczne, 2010, 48, 3, s. 75-87.

${ }^{25}$ Por. J.J. Gross (red.), Handbook of emotion regulation, New York 2007.

${ }^{26}$ Por. K. Rajewska-Rynkowska, Schematy przywiazania do obiektu religijnego, s. 31-35. 
od treści stresujących ${ }^{27}$, wypierają myśli związane z napięciem oraz stosują dysocjacyjne mechanizmy obronne i zahamowanie ekspresji emocji ${ }^{28}$. Będący konsekwencją takich zachowań słaby dostęp do negatywnych emocji ${ }^{29}$ powoduje, że przeżycie emocjonalne zostaje zubożone. Osoby te odczuwają wysoki poziom całkowicie nieuświadamianego lęku, jednak jest on trudno zauważalny, ponieważ mają silną tendencję do izolowania i wypierania lęku, zarówno $\mathrm{w}$ procesach wewnętrznych, jak i interpersonalnych ${ }^{30}$. $\mathrm{Z}$ kolei osoby o stylu ambiwalentnym mają tendencję do nasilonego utrzymywania uwagi na bodźcach związanych $\mathrm{z}$ afektem (w szczególności z afektem negatywnym) oraz zbliżania się do wszelkich bodźców związanych z sytuacją stresową, co prowadzi do stanu chronicznej dysregulacji emocjonalnej. Lęk odczuwany przez te osoby jest łatwo zauważalny, ponieważ są one go świadome i ujawniają go w zachowaniu ${ }^{31}$. Wskazuje to na obecność zachowań charakterystycznych dla braku przetwarzania emocjonalnego. W szczególności ma to miejsce, kiedy negatywnym wspomnieniom towarzyszy automatycznie podwyższona aktywacja myśli związanych ze stresem i mentalne „przeżuwanie” myśli, wspomnień i uczuć dotyczących sytuacji stresowej ${ }^{32}$.

Rodzina zastępcza to rodzina wychowująca dzieci, których rodzice nie żyją bądź nie są w stanie ich wychowywaćs3. Pod kuratelę pieczy zastępczej kieruje się dzieci i młodzież wymagającą zapewnienia całkowitej opieki wychowawczej i pozbawioną stałego kontaktu z rodziną naturalną. W literaturze przedmiotu wychowankowie rodzin zastępczych są jednoznacznie opisywani jako osoby, które na wczesnych etapach rozwojowych doświadczyły zaniedbania ze strony opiekunów, przemocy, krzywd, porzucenia, osamotnienia, czy traumy ${ }^{34}$. Nowak i inni ${ }^{35}$ donoszą, że jedną z podstawowych jed-

${ }_{27}$ M. Mikulincer, V. Florian, Exploring Individual Differences in Reactions to Mortality Salience: Does Attachment Style Regulate Terror Management Mechanisms? Journal of Personality and Social Psychology, 2000, 79, 2, s. 260-273.

${ }^{28}$ M. Mikulincer, Adult Attachment Style and Affect Regulation: Strategic Variations in Self-Appraisals, Journal of Personality and Social Psychology, 1998, 75, 2, s. 420-435.

${ }^{29}$ M. Mikulincer, V. Florian, Exploring Individual Differences, s. 260-273.

${ }^{30}$ J.M. Fuendeling, Affect Regulation as a Stylistic Process, s. 291-322.

31 Tamże.

${ }^{32}$ M. Mikulincer, Adult Attachment Style and Affect Regulation, s. 420-435.

${ }^{33}$ W. Okoń, Nowy stownik pedagogiczny, Warszawa 2001, s. 337.

${ }^{34}$ M. Liciński, Rodzina zastępcza dla dzieci bez przyszłości, Problemy Opiekuńczo-Wychowawcze, 2009, 5, s. 23-28; K. Mickiewicz, Funkcjonowanie rodzinnej pieczy zastępczej. Problematyka psychologiczna, [w:] Administracja opiekuńcza, red. M. Szreniawska, Lublin 2015, s. 344-355; M. Ruszkowska, Diagnoza rodzin zastępczych w obliczu dylematów wspótczesności, Warszawa 2013; taże, Rodzina zastępcza jako środowisko opiekuńczo-wychowawcze, Warszawa 2013; L. Telka, Sytuacja dziecka wychowywanego poza rodzina własna - analiza wybranych badan, [w:] Zagrożone dzieciństwo. Rodzinne i instytucjonalne formy opieki, red. M. Kolankiewicz, Warszawa 1998, s. 93-108.

${ }^{35}$ M. Nowak, A. Gawęda, M. Janas-Kozik, Prowokacja odrzucenia czy pragnienie bliskości. Znaczenie relacji rodzic zastępczy - dziecko dla niwelowanie deficytów wynikających z diagnozy „zabrudzenie więzi", Psychiatra i Psychologia Kliniczna, 2011, 11, s. 60. 
nostek diagnostycznych identyfikowanych wśród dzieci przebywających $\mathrm{w}$ rodzinach zastępczych jest zaburzenie więzi. Reaktywne zaburzenie więzi [kod diagnostyczny 313.89 (F94.10) za DSM-5 ${ }^{36}$ ] należy do grupy zaburzeń pourazowych i związanych z czynnikiem stresowym. Wśród przyczyn tego zaburzenia podaje się między innymi doświadczenie przez dziecko szeregu skrajności w zakresie niewystarczającej opieki, na przykład zaniedbanie lub pozbawienie społecznych kontaktów, przybierające formę nieustannego braku poczucia bezpieczeństwa, stymulacji i miłości wymaganych od dorosłych opiekunów, czy powtarzające się zmiany podstawowych opiekunów, które ograniczają możliwości rozwoju stabilnego przywiązania (np. częste zmiany $w$ rodzinach zastępczych). W odpowiedzi na opisany charakter deprywacji, u dziecka pojawia się utrwalony wzorzec powściągliwych i wycofanych emocjonalnie zachowań wobec dorosłych opiekunów związany $\mathrm{z}$ nieszukaniem przez dziecko pocieszenia $\mathrm{w}$ trudnej sytuacji oraz brak reakcji na pocieszanie $\mathrm{w}$ trudnej sytuacji. Ponadto, pojawiają się przewlekłe zakłócenia społeczne i emocjonalne, na przykład ograniczona zdolność do pozytywnych reakcji emocjonalnych, czy epizody trudnej do wyjaśnienia drażliwości, smutku lub lęku, występujące nawet podczas niezagrażającej interakcji z dorosłymi opiekunami. I choć zaburzenie więzi diagnozowane jest w okresie wczesnodziecięcym, to jest możliwe, że jego konsekwencje są obserwowane także na dalszych etapach rozwojowych. Jest to tym bardziej interesujące, że studia nad funkcjonowaniem dorosłych wychowanków rodzin zastępczych szczególnie w okresie przejścia między opieką zastępczą a dorosłością (ang. transition from foster care to adulthood) ${ }^{37}$ wydają się marginalne.

Na podstawie przedstawionych powyżej analiz teoriopoznawczych dotyczących wzajemnych powiązań pomiędzy jakością więzi przywiązaniowej, aleksytymią a zdolnością do samoregulacji emocjonalnej pod postacią przetwarzania emocjonalnego postawiono hipotezy badawcze, które stanowią przedmiot przedstawionych w dalszej części badań.

1. Istnieją różnice w jakości więzi przywiązaniowej, w zakresie lęku i unikania, aleksytymią i przetwarzaniem emocjonalnym między wychowankami rodzin zastępczych a wychowankami rodzin biologicznych.

2. Uwzględniając poza jakością więzi przywiązaniowej przetwarzanie emocjonalne, można lepiej wyjaśniać aleksytymię u wychowanków rodzin zastępczych.

${ }^{36}$ Kryteria Diagnostyczne z DSM-5. Desk Reference, Edra Urban \& Partner, Wrocław 2015, s. 137.

${ }^{37}$ M.E. Courtney i in., Foster youth transitions to adulthood: A longitudinal view of youthleaving care, Child Welfare, 2001, 80, s. 685-717. 


\section{Metoda}

\section{Uczestnicy}

W badaniu wzięło udział 61 osób. 29 uczestników badania stanowili wychowankowie rodzin zastępczych. W większości byli to wychowankowie rodzin zastępczych spokrewnionych, w niektórych przypadkach mieli za sobą doświadczenie pobytu $\mathrm{w}$ domu dziecka, żadna osoba nie była sierotą. Biorące udział w badaniu kobiety $(N=15)$, w wieku 20-27 lat $(M=22.4 ; S D=2.64)$, były uczestniczkami projektu „Rozwój i upowszechnianie aktywnej integracji przez Powiatowe Centrum Pomocy Rodzinie w Żaganiu”, prowadzonego we współpracy z Fundacją "Nasz Dom”. Program miał na celu społeczną i zawodową reintegrację osób z rodzin zastępczych. Biorący udział w badaniu mężczyźni $(N=14)$, w wieku 19-27 lat $(M=21.36$; $S D=2.2)$ byli uczestnikami programu „Przedsiębiorstwo Społeczne WINDA - otwarciem drogi zawodowej dla młodzieży z rodzin zastępczych" prowadzonego przez Fundację "Nasz Dom”. W ramach projektu prowadzono program reintegracji społecznej oparty na pracy społecznościowej. Celem programu była między innymi praca nad większą zdolnością do uświadamiania sobie emocji, ich różnicowania oraz umiejętności ich werbalizacji. Każdy uczestnik brał udział w projekcie przez 6 miesięcy. Pozostałe 32 zbadane osoby pochodziły z rodzin biologicznych. W grupie tej było 15 kobiet i 17 mężczyzn w wieku 20-33 lat $(M=26.37 ; S D=4.3)$.

\section{Materiały i procedura badania}

W badaniu wykorzystano pakiet trzech kwestionariuszy, który zawierał:

1. Kwestionariusz doświadczeń w bliskich związkach (ang. Experiences in Close Relationships Scale - ECR) ${ }^{38}$. Składa się on z 36 stwierdzeń dotyczących doświadczeń w związkach, do których ustosunkowuje się osoba badana korzystając z 7-stopniowej skali Likerta, w której 1 oznacza "zdecydowanie nie zgadzam się“, natomiast 7 - „zdecydowanie zgadzam się“. Kwestionariusz tworzą dwie podskale (każda składa się z 18 twierdzeń) reprezentujące podstawowe wymiary przywiązania: unikanie i lęk. Kombinacja wyników uzyskanych na tych wymiarach wskazuje na posiadanie

${ }^{38}$ K.A. Brennan, C.L. Clark, P.R. Shaver, Self-Report Measurement of Adult-Attachment. An Integrative Overview, [w:] Attachment Theory and Close Relationships, red. J.A. Simpson, W.S. Rholes, New York 1998, s. 46-76; polska adaptacja K. Rajewska-Rynkowska, Schematy przywiazania do obiektu religijnego. 
jednego z czterech typów przywiązania ${ }^{39}$ : ufnego, zaabsorbowanego, lękowego i odrzucającego.

2. Skala Aleksytymii (ang. Toronto Alexithymia Scale - TAS-26) ${ }^{40}$. Składa się ona z 35 stwierdzeń, z których 26 jest poddawanych analizie psychometrycznej. Osoba badana posługuje się 5-stopniową skalą Likerta do opisu swojego zachowania, gdzie 1 oznacza, że stwierdzenie opisuje ją w stopniu minimalnym, a 5 - że opisuje ją w dużym stopniu. W strukturze TAS-26 można wyróżnić trzy czynniki odpowiadające elementom aleksytymii: trudności w rozpoznawaniu uczuć i doznań fizycznych, operacyjny styl myślenia i ubóstwo wyobraźni.

3. Skala Przetwarzania Emocjonalnego (ang. Emotional Procesing Scale EPS ${ }^{41}$. Składa się z 25 pozycji o charakterze stwierdzeń dotyczących przetwarzania emocjonalnego. Pozycje kwestionariusza tworzą pięć podskal, składających się z pięciu stwierdzeń każda. Podskale odnoszą się do deficytów przetwarzania emocjonalnego, takich jak: tłumienie, brak przetwarzania, brak regulacji, unikanie, zubożone doświadczanie emocji. Wypełnianie kwestionariusza poprzedzone jest instrukcją, w której badany jest proszony o wspomnienie minionego tygodnia oraz wyłonienie i opisanie najsilniejszej pozytywnej i negatywnej emocji jaką odczuwał. Następnie zadaniem osoby badanej jest ustosunkowanie się do 25 stwierdzeń opisujących to, co czuła lub jak zachowywała się w minionym tygodniu. Osoba dokonuje oszacowania posługując się skalą odpowiedzi typu likertowskiego od 0 do 9, gdzie 0 oznacza „zupełnie nie zgadzam się”, natomiast 9 - „w pełni zgadzam się"42.

Badanie prowadzono indywidualnie. Biorące w nim udział osoby poproszono o wypełnienie pakietu kwestionariuszy i zwrot osobie przeprowadzającej badanie.

\section{Wyniki}

Wartość statystyk opisowych, współczynniki rzetelności dla poszczególnych narzędzi oraz współczynniki korelacji pomiędzy mierzonymi zmiennymi przedstawia tabela 1 .

${ }^{39}$ K. Bartholomew, L.M. Horowitz, Attachment Styles among Young Adults, s. 226-244.

${ }^{40}$ G.J. Taylor, R.M. Bagby, J.D.A. Parker, The development and regulation of affect, s. 24-25; polska adaptacja T. Maruszewski, E. Ścigała, Emocje - aleksytymia - poznanie.

${ }^{41}$ R. Baker i in., Emotional Processing Research. Information booklet - materiał niepublikowany, 2007; polska wersja eksperymentalna D. Górska, A. Jasielska, Konceptualizacja przetwarzania emocjonalnego, s. 75-87.

${ }_{42}$ Wynik na Skali Przetwarzania Emocjonalnego interpretowany jest - że im wyższa jego wartość, tym deficyty w zakresie przetwarzania emocjonalnego są wyższe. 


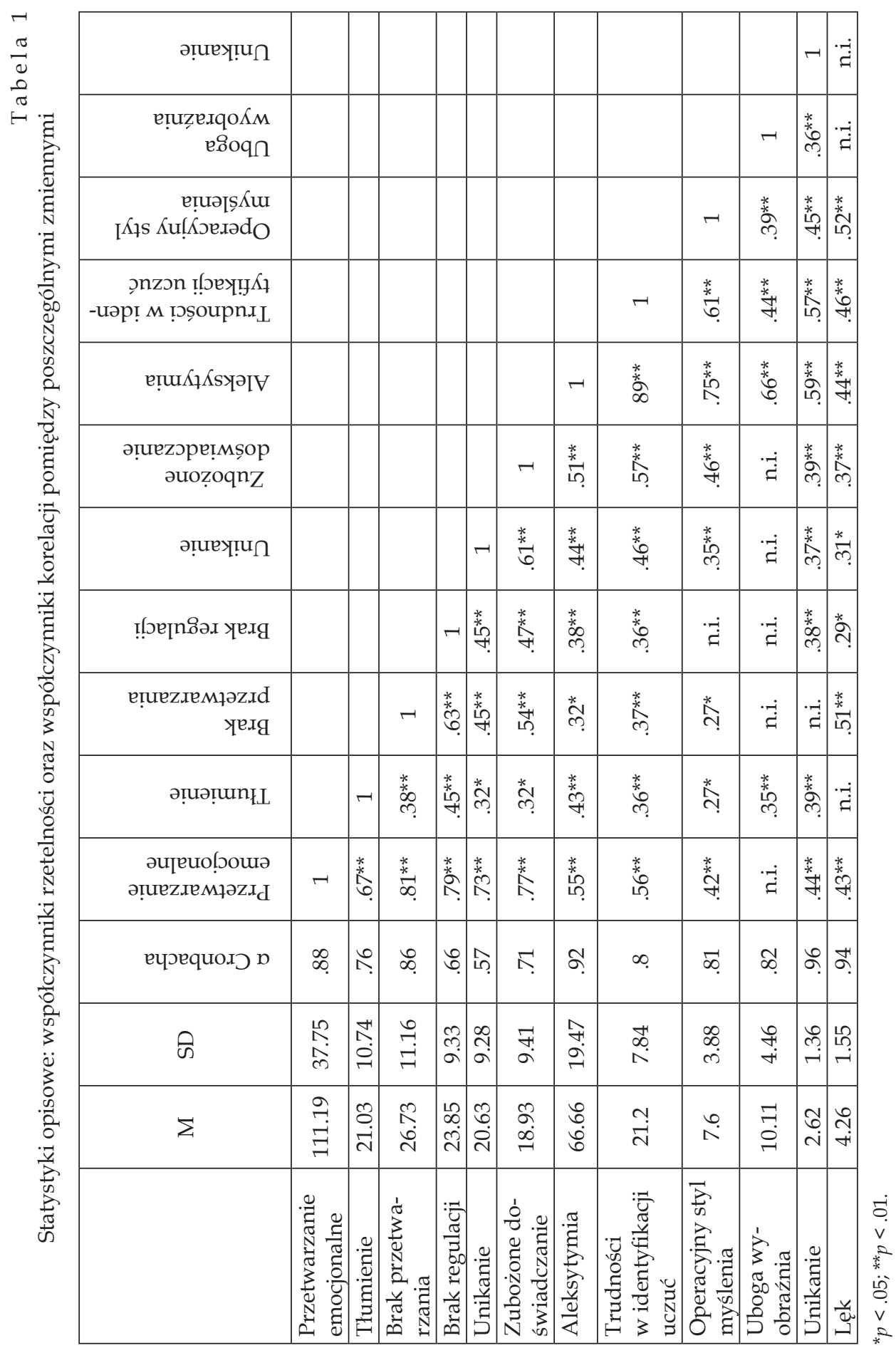


Przed przystąpieniem do statystycznej weryfikacji hipotez badawczych poddano analizie założenie mówiące o różnych stylach przywiązania u osób pochodzących z rodzin zastępczych i biologicznych z tendencją do wyższej frekwencyjności pozabezpiecznych wzorców przywiązania u osób pochodzących $\mathrm{z}$ rodzin zastępczych ${ }^{43}$. W tym celu przeprowadzono analizę testem $\chi^{2}$ $(3, N=62)=8.24 ; p<.05$, który okazał się istotny statystycznie. Jak założono, badane grupy różniły się $\mathrm{w}$ zakresie manifestowanych wzorców przywiązania, co przedstawia rycina 1 .

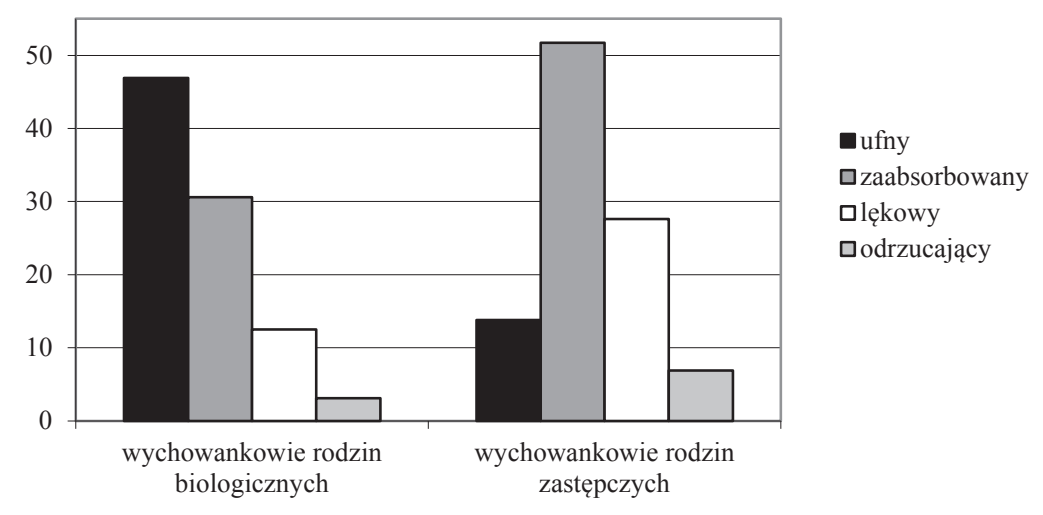

Ryc. 1. Częstotliwość występowania poszczególnych stylów przywiązania w badanych grupach

Blisko połowa wychowanków rodzin biologicznych manifestuje styl ufny, podczas gdy dominującym stylem u ponad $50 \%$ osób pochodzących z rodzin zastępczych jest styl ambiwalentny. Ponadto, osób manifestujących styl lękowy jest $\mathrm{w}$ grupie wychowanków rodzin zastępczych dwukrotnie więcej niż w drugiej grupie. Dokonując uproszczonej dwukategorialnej klasyfikacji - styl ufny i styl nieufny obejmujący trzy style pozabezpieczne widać, że wśród uczestników badania pochodzących z rodzin zastępczych istotnie częściej manifestowany jest nieufny wzorzec przywiązania, $\chi^{2}(1, N=62)=7.76$; $p<.01$.

$\mathrm{W}$ dalszej kolejności dokonano porównań międzygrupowych pomiędzy badanymi grupami w zakresie poszczególnych zmiennych ${ }^{44}$. Analiza testem t-Studenta dla prób niezależnych wykazała, że istnieją statystycznie istotne różnice w większości z nich. Dokładne dane przedstawia tabela 2.

${ }^{43}$ Por. badania osób z grupy wysokiego ryzyka patologii społecznej, N.S. Weinfield, L.A. Sroufe, B. Egeland, Attachment from Infancy to Early Adulthood in a High-Risk Sample: Continuity, Discontinuity, and Their Correlates, Child Development, 2000, 71, 3, s. 695-702.

${ }^{44} \mathrm{~W}$ związku z tym, że jeden z wychowanków rodziny zastępczej nie wypełnił Skali Aleksytymii, statystyki uwzględniające zmienną aleksytymii zostały przeprowadzone dla grupy o zmniejszonej liczebności $(\mathrm{N}=60)$. 


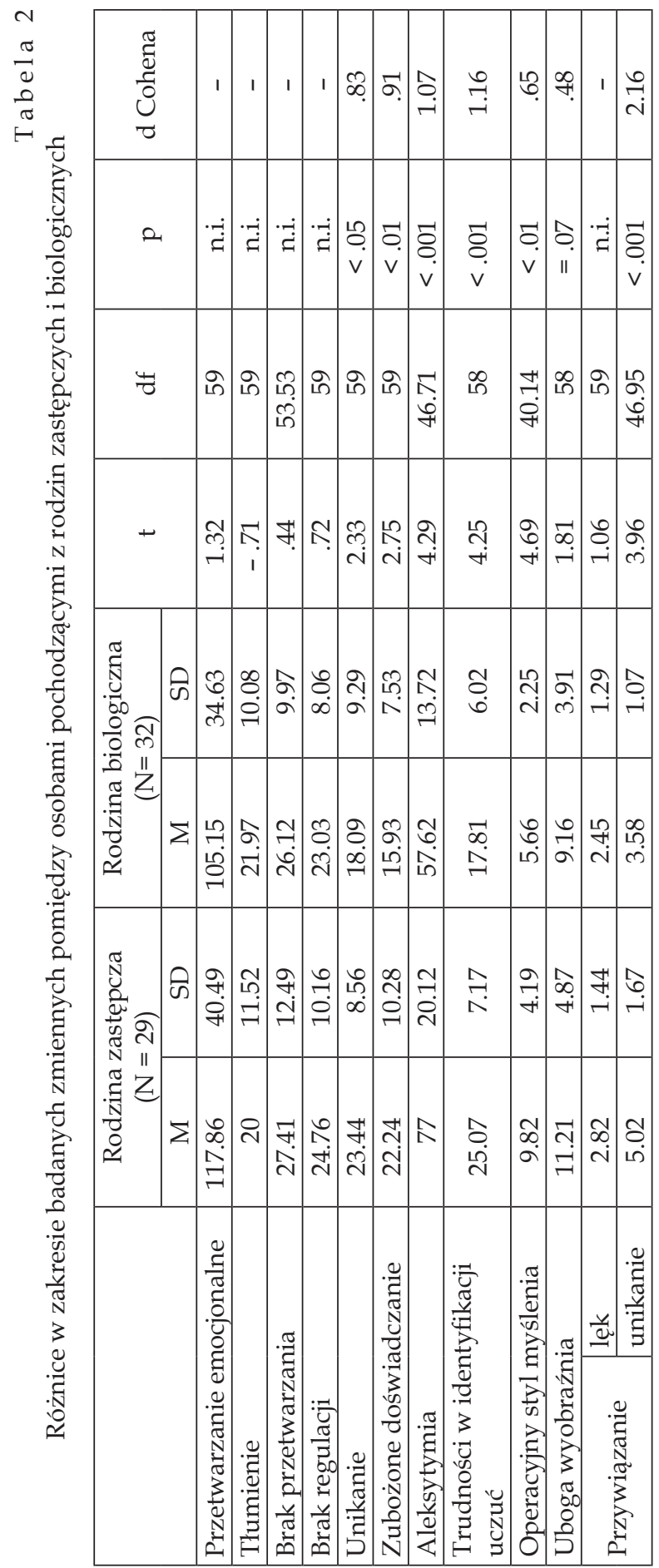


W obrębie przetwarzania emocjonalnego występują różnice $\mathrm{w}$ zakresie dwóch deficytów - unikania i zubożonego doświadczania, które są wyższe u wychowanków rodzin zastępczych. Wielkość efektu wskazuje na silny związek między tymi deficytami a typem rodziny. W zakresie ogólnego poziomu aleksytymii i jej wymiaru trudności w identyfikowaniu emocji również obserwuje się silny związek między tymi cechami a typem rodziny. Obydwie zmienne są wyższe u wychowanków rodzin zastępczych. Kolejne wymiary aleksytymii, czyli operacyjny styl myślenia i uboga wyobraźnia również są wyższe u wychowanków rodzin zastępczych, a siła efektu wskazuje na średni związek między tymi cechami a typem rodziny. W zakresie wymiaru relacji przywiązaniowej obserwuje się większe natężenie unikania u wychowanków rodzin zastępczych, a wielkość efektu wskazuje na bardzo silny związek między wymiarem unikania a typem rodziny.

W celu przewidzenia udziału wymiarów stylu przywiązania i deficytów przetwarzania emocjonalnego jako predyktorów aleksytymii zaplanowano przeprowadzenie hierarchicznej analizy regresji dla poszczególnych grup. Jako pierwsze przeprowadzono analizy korelacyjne, zaprezentowane w tabeli 3.

Tabela 3 Analizy korelacyjne między aleksytymią, przetwarzaniem emocjonalnym a wymiarami przywiązania w badanych grupach

\begin{tabular}{|c|c|c|c|}
\hline & & Aleksytymia & $\begin{array}{l}\text { Przetwarzanie } \\
\text { emocjonalne }\end{array}$ \\
\hline \multicolumn{2}{|l|}{ Aleksytymia } & 1 & \\
\hline \multirow{2}{*}{\multicolumn{2}{|c|}{ Przetwarzanie emocjonalne }} & RZ: .62 & \multirow{2}{*}{1} \\
\hline & & RB: $.47^{* *}$ & \\
\hline \multirow{4}{*}{ Przywiązanie } & \multirow{2}{*}{ lęk } & RZ: $.48^{*}$ & RZ: $.61^{*}$ \\
\hline & & RB: n. i. & RB: n. i. \\
\hline & \multirow{2}{*}{ unikanie } & RZ: $.59^{* *}$ & RZ: $.27^{\text {tht }}$ \\
\hline & & RB: $.67^{* *}$ & RB: $.58^{* *}$ \\
\hline
\end{tabular}

${ }^{*} p<.05 ;{ }^{* *} p<.01 ;{ }^{* * *} p=.08$.

RZ - wychowankowie rodziny zastępczej

RB - wychowankowie rodziny biologicznej

Uzyskane wyniki ujawniają odmienne wzorce zależności w badanych grupach. U wychowanków rodzin zastępczych występują silne dodatnie korelacje między wszystkimi badanymi zmiennymi, z wyłączeniem związku między przetwarzaniem emocjonalnym a wymiarem unikania w przywiązaniu na pograniczu istotności statystycznej. Z kolei, w grupie osób pochodzących z rodzin biologicznych nie zaobserwowano związku między wymia- 
rem lęku w przywiązaniu a aleksytymią i przetwarzaniem emocjonalnym, co $\mathrm{w}$ konsekwencji nie pozwala na wprowadzenie wymiaru lęku jako predyktora w analizie regresji. Ponadto, zaobserwowano wyższe współczynniki korelacji dla wymiaru unikania w przywiązaniu a aleksytymią (różnica nie jest istotna statystycznie) i przetwarzaniem emocjonalnym (różnica istotna na pograniczu $\mathrm{z}=1.43 ; p=.07)$, niż wśród uczestników badania pochodzących $\mathrm{z}$ rodzin zastępczych.

W dalszej kolejności przeprowadzono hierarchiczne analizy regresji, w których zmienną wyjaśnianą był poziom aleksytymii a predyktorami - specyficzne dla grupy wymiary przywiązania oraz przetwarzanie emocjonalne. W celu wyjaśnienia aleksytymii na postawie wymiaru lęku w przywiązaniu oraz przetwarzania emocjonalnego w grupie wychowanków rodzin zastępczych, w pierwszym kroku do równania regresji wprowadzono wymiar lęku, a w drugim przetwarzanie emocjonalne. Zaproponowany model istotnie lepiej pozwala przewidywać aleksytymię, na co wskazuje istotna zmiana $R^{2}$ (zmiana $=0.17 ; p<.05)$. Model ten okazał się dobrze dopasowany do danych $(F 2,25)=8.43 ; p<.01)$. Obydwa predyktory wyjaśniają $40 \%$ wariancji i pozwalają $\mathrm{w}$ istotny sposób przewidywać aleksytymię, choć tylko przetwarzanie emocjonalne jest predyktorem istotnym statystycznie $(\beta=0.53 ; p<.05)$. Następnie zastosowano równanie regresyjne dla tej samej grupy, gdzie w pierwszym kroku wprowadzono wymiar unikania w przywiązaniu. Także ten złożony model istotnie lepiej pozwala przewidywać aleksytymię, na co wskazuje istotna zmiana $R^{2}$ (zmiana $\left.=0.22 ; p<.001\right)$. Model okazał się dobrze dopasowany do danych (F 2.25) = 17.53; $p<.001)$. Obydwa predyktory wyjaśniają ponad połowę wariancji $58 \%$, przy czym przetwarzanie emocjonalne jest silniejszym predyktorem $(\beta=0.5 ; p<0.001)$ aleksytymii, niż unikanie $(\beta=0.46 ; p<.05)$.

W grupie wychowanków rodzin biologicznych przeprowadzono analizę regresji dla zmiennej zależnej aleksytymia, w pierwszym kroku wprowadzając wymiar unikania z przywiązania, a w drugim przetwarzanie emocjonalne. Zaproponowany model nie pozwala istotnie lepiej przewidywać aleksytymii - zmiana $R^{2}$ nie była istotna statystycznie. Wymiar unikania wyjaśnia $44 \%$ wariancji.

Specyficzna konstrukcja Skali Przetwarzania Emocjonalnego umożliwia uzyskanie danych o charakterze jakościowym. Wypełnianie Skali jest poprzedzone pytaniem: jaką najsilniejszą emocję pozytywną i negatywną odczuwały w minionym tygodniu. Udzielone pisemne odpowiedzi poddano kategoryzacji ze względu na obecność lingwistycznej reprezentacji emocji. Pierwszą kategorię stanowi deklaracja braku emocji, drugą wypowiedź zawierająca konkretną nazwę emocji (np. „Radość“, "Złość i przygnębienie spowodowane alkoholizmem rodziców“), trzecią wypowiedź pozbawiona emocji (np. 
„Zgubiłam klucze, a później je znalazłam“, „Moją negatywną emocją był spór z innym pracownikiem firmy lakierniczej“汭. Zsumowane dane zarówno dla emocji pozytywnej i negatywnej poddano analizie testem $\chi^{2}(2, \mathrm{~N}=122)=$ 9.45; $p<.01$ celem ustalenia, czy obecność lingwistycznej reprezentacji emocji w wypowiedziach jest różna w badanych grupach. Wartość statystyki okazała się istotna. Ponad jedna trzecia (36\%) wychowanków rodzin zastępczych udzieliła odpowiedzi bez wskazania emocji. W ten sam sposób postąpiło tylko $12 \%$ osób z drugiej grupy. Dokładne dane dla poszczególnych kategorii przedstawia rycina 2 .

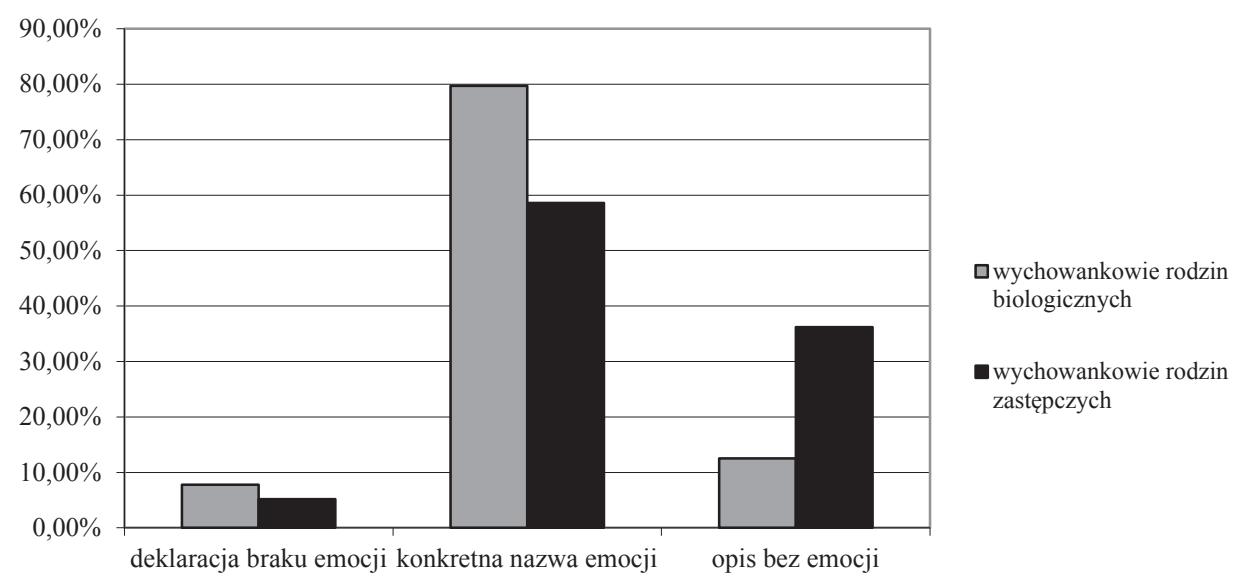

Ryc. 2. Częstotliwość występowania lingwistycznej reprezentacji emocji $\mathrm{w}$ badanych grupach

\section{Dyskusja}

Zgodnie z przewidywaniami, wyniki uzyskane przez osoby dorosłe o różnych stylach przywiązania w zakresie deficytów przetwarzania emocjonalnego potwierdzają opisywane w literaturze przedmiotu odmienne profile regulacji emocjonalnej ${ }^{45}$. Zaobserwowane u wychowanków rodzin zastępczych, u których dominuje pozabezpieczny styl przywiązania, deficyty przetwarzania emocjonalnego korespondują z danymi mówiącymi o niemożności efektywnej regulacji emocji u tych osób ${ }^{46}$. Przykładem tej zależności może być unikanie - jeden z deficy tów przetwarzania emocjonalnego - zaobserwowane

${ }^{45}$ K. Rajewska-Rynkowska, Schematy przywiazania do obiektu religijnego.

${ }^{46}$ L.J. Bridges, W.S. Grolnick, J.P. Connell, Infant emotion regulation with mothers and fathers, Infant Behavior and Development, 1997, 20, s. 47-57. 
u osób manifestujących lękowy styl przywiązania ${ }^{47}$ czy tłumienie ekspresji wrogości charakteryzujące „zależny depresyjny styl przetwarzania informacji" występujący u osób o zaabsorbowanym stylu przywiązania ${ }^{48}$. Przeciwnie zaś funkcjonują osoby o bezpiecznym stylu przywiązania, które stosują konstruktywne, instrumentalne strategie radzenia sobie ${ }^{49}$. Dodatkowo bezpieczny styl przywiązania wiąże się ze zrównoważonym obdarzaniem uwagą zarówno bodźców afektywnych, jak i innych, co stanowi najbardziej optymalny sposób funkcjonowania ${ }^{50}$, co może sprzyjać niezakłóconemu przetwarzaniu emocjonalnemu.

Zaobserwowany u wychowanków rodzin zastępczych związek pomiędzy aleksytymią a lękiem stwierdzono także we wcześniejszych pracach ${ }^{51}$. Prawdopodobnie ograniczone zdolności aleksytymików w zakresie kognitywnego przetwarzania emocji prowadzą do impulsywnej i słabo kontrolowanej reakcji na negatywną stymulację ${ }^{52}$, którą można utożsamiać z deficytami w zakresie przetwarzania emocjonalnego. Z kolei, zaobserwowany związek aleksytymii z przywiązaniem koresponduje z badaniami, które pokazały, że najsilniej z jakością środowiska rodzinnego koreluje aspekt aleksytymii związany $\mathrm{z}$ trudnością $\mathrm{w}$ rozpoznawaniu emocji ${ }^{53}$. Ponadto, badania ujawniły powiązanie między słabym zrozumieniem emocji w dorosłym życiu a doświadczeniem dorastania w rodzinach o wysokim wskaźniku ekspresji emocji negatywnych ${ }^{54}$, co może być charakterystyczne dla funkcjonowania rodzin pochodzenia wychowanków rodzin zastępczych.

Uzyskane wyniki poza opisem deficytów w zakresie funkcjonowania emocjonalnego osób wychowanych w różnych rodzinach umożliwiają także wyjaśnianie przyczyn leżących u podłoża tego zjawiska. Wadliwe funkcjonowanie emocjonalne pod postacią aleksytymii i deficytów przetwarzania

${ }^{47} \mathrm{~W}$. Eng $\mathrm{i}$ in., Attachment in individuals with social anxiety disorder: The relationship among adult attachment styles, social anxiety, and depression, Emotion, 2001, 1, 4, s. 365-380.

${ }^{48}$ Zuroff i Fitzpatrick, 1995 za: J.M. Fuendeling, Affect Regulation as a Stylistic Process, s. 291-322.

${ }^{49}$ M. Mikulincer, Adult Attachment Style and Affect Regulation, s. 420-435.

${ }^{50}$ J.M. Fuendeling, Affect Regulation as a Stylistic Process, s. 291-322.

${ }^{51}$ J.D. Bagby, G.J. Taylor, Anxiety and depressive disorders and a note on personality disorders, [w:] Disorders of affect regulation; alexithymia in medical and psychiatric illness, red. G.J. Taylor, R.M. Bagby, J.D.A. Parker, Cambridge 1997, s. 138-165; J.D.A. Parker, G.J. Taylor, Relations between alexithymia. Personality, and affects, [w:] Disorders of affect regulation, s. 67; K. Honkalampi i in., Depression is strongly associated with alexithymia in the general population, Journal of Psychosomatic Research, 2000, 48, s. 99-104.

52 R. Brzeziński, Dwie dekady koncepcji aleksytymii, Psychiatria Polska, 1995, 29, s. 443-454.

${ }^{53}$ S. Kench, H.J. Irwin, Alexithymia and childhood family environment, Journal of Clinical Psychology, 2000, 5, s. 737-745.

${ }^{54}$ J. Dunn, C. Creps, J. Brown, Children's family relationships between two and five: Developmental changes and individual differences, Social Development, 1996, 3, s. 230-250. 
emocjonalnego można wyjaśnić specyficzną charakterystyką i organizacją reprezentacji emocji u wychowanków rodzin zastępczych. $W$ ich przypadku istotny może być zarówno niespecyficzny mechanizm tworzenia i wykorzystania reprezentacji emocji oraz specyficzna reprezentacja emocji będąca konsekwencją wczesnodziecięcych doświadczeń.

Uzyskane wyniki świadczą o niewystarczającej reprezentacji emocji u wychowanków rodzin zastępczych, czego dowodem jest zaobserwowany wyższy poziom aleksytymii, jak i obecność uboższej lingwistycznej reprezentacji emocji. Osoby te blisko trzykrotnie częściej, w porównaniu z osobami pochodzącymi $\mathrm{z}$ rodzin funkcjonalnych $\mathrm{w}$ wypowiedzi na temat emocji, nie realizowały ekspresywnej funkcji języka, polegającej na powiadamianiu odbiorcy o doznaniach uczuciowych nadawcy wypowiedzi i informowaniu go o stanie emocjonalnym mówiącego ${ }^{55}$ i zamiast słów jednoznacznie denotujących znaczenie emocjonalne stosowały wyrażenia o konotacjach emocjonalnych ${ }^{56}$.

Wyniki regresji pokazują, że w większym stopniu o aleksytymii wychowanków rodzin zastępczych decyduje przetwarzanie emocjonalne, niż biologicznie zdeterminowane przywiązanie. Wydaje się, że przywiązanie jest gatunkowym potencjałem tworzenia reprezentacji, której treści dostarczają wydarzenia z okresu wczesnego dzieciństwa, natomiast w dorosłości przywiązanie jest warunkiem koniecznym, ale niewystarczającym do wyjaśnienia na przykład aleksytymii i większą rolę zaczynają odgrywać mechanizmy regulacji emocjonalnej, na przykład pod postacią przetwarzania emocjonalnego.

Ponieważ pozabezpieczne style przywiązania są związane $\mathrm{z}$ wewnętrznymi schematami czy reprezentacjami, które zawierają braki w zakresie integracji informacji afektywnych z poznawczymi czy w obszarze kognitywnego przetwarzania emocji (np. pod postacią aleksytymii) ${ }^{57}$, skutkuje to deficytami $\mathrm{w}$ zakresie na przykład uwzględnionego $\mathrm{w}$ badaniu przetwarzania emocjonalnego. Idąc dalej, można przypuszczać, że posiadane przez osoby manifestujące pozabezpieczny styl przywiązania prymitywniejsze reprezentacje emocji zawierają przede wszystkim informacje konkretne, którym brak obróbki charakterystycznej dla wyższych pięter organizacji poznawczej. To ubóstwo może być konsekwencją dominujących doznań negatywnych u wychowanków rodzin zastępczych ${ }^{58}$. Ponadto, wyższy poziom negatywnej emo-

${ }^{55}$ E. Marczewski (red.), Stownik terminów nauki o języku, Warszawa 1985.

56 A. Jasielska, Zastosowanie analizy transkrypcji do pomiaru inteligencji emocjonalnej, Psychologia. Edukacja i Społeczeństwo, 2007, 4, 1, s. 29-45; G.R. Semin i in., Cultural perspectives on the linguistic representation of emotion and emotion events, Cognition and Emotion, 2002, 16, 1, s. 11-28.

${ }_{57}$ J.D. Bagby, G.J. Taylor, Affect dysregulation and alexithymia, [w:] Disorders of affect regulation, s. 41.

${ }^{58}$ D. Bruskas, Care: A Vulnerable Population at Risk, Journal of Child and Adolescent Psychiatric Nursing, 2008, 21, s. 70-77. 
cjonalności przeciąża możliwości systemu regulacji emocji ${ }^{59}$, z czego wynikają deficyty przetwarzania emocjonalnego.

Nie bez wpływu na uzyskane wyniki w grupie osób pochodzących z rodzin zastępczych pozostaje historia ich życia ${ }^{60}$. Dane $z$ longitudinalnych badań z udziałem osób z grupy wysokiego ryzyka patologii społecznej świadczą o silnej tendencji u nich do zmian stylu przywiązania na przestrzeni czasu. Zdaniem autorów, rezultat taki jest spowodowany charakterystycznymi dla tej grupy społecznej, licznymi, chaotycznymi wydarzeniami życiowymi, takimi jak: doświadczenie maltretowania w dzieciństwie, depresja mat$\mathrm{ki}$, zaburzenia funkcjonowania rodziny $\mathrm{w}$ okresie dorastania ${ }^{61}$. Wyniki te są zgodne z teoretycznymi przewidywaniami Bowlby'ego ${ }^{62}$, który łączył wystąpienie zmian $\mathrm{w}$ operacyjnych modelach przywiązania $\mathrm{z}$ takimi negatywnymi wydarzeniami życiowymi, jak: śmierć, poważna przewlekła choroba lub zaburzenia psychiczne rodzica, nadużywanie alkoholu i narkotyków przez opiekuna, opieka zastępcza, rozwód rodziców, wychowywanie przez samotnego rodzica, doświadczenie fizycznego lub seksualnego wykorzystania. Podobna zależność dotyczy wyróżnianej przez niektórych autorów aleksytymii wtórnej ${ }^{63}$, która w przypadku osób pochodzących z rodzin zastępczych może wzmacniać aleksytymię pierwotną. Aleksytymia wtórna stanowi konsekwencję przewlekłego stresu towarzyszącego traumie (jak np. gwałt, kazirodztwo) lub adaptacji podczas ciężkiej choroby psychosomatycznej (np. wieloletnie dializy) lub psychicznej ${ }^{64}$. W ujęciu tym aleksytymia ma charakter reaktywny i jest sposobem represyjnego radzenia sobie z emocjami. Taki stan permanentnego stłumienia negatywnych emocji odcina bolesne przeżycia i paradoksalnie chroni przed depresją. Uzyskane dane prowadzą do konkluzji, że zarówno trudne wczesnodziecięce doświadczenia, jak i wypracowane na ich bazie mechanizmy radzenia sobie znacząco determinują jakość dorosłego życia emocjonalnego wychowanków rodzin zastępczych.

${ }^{59}$ G. Kochanska, K.C. Coy, Child emotionality and maternal responsiveness as predictors of reunion behaviors in the strange situation: Links mediated and inmediated by separation distress, Child Development, 2002, 73, s. 228-240.

60 A. Jasielska, A. Zglenicka, Styl przywiazania i deficyty przetwarzania emocjonalnego u ofiar przemocy domowej, Poznań 2016.

${ }^{61}$ N.S. Weinfield, L.A. Sroufe, B. Egeland, Attachment from Infancy to Early Adulthood, s. $695-702$.

${ }^{62}$ Bowlby'ego (1953) za: E. Waters, N.S. Weinfield, C.E. Hamilton, The Stability of Attachment Security, s. 703-706.

${ }^{63} \mathrm{H}$. Freyberger, Supportive psychotherapeutic techniques in primary and secondary alexithymia, Psychotherapy and Psychosomatics, 1977, 28, s. 337-324; R. Tomalski, Aleksytymia i dysocjacja, Psychoterapia, 2008, 2, 145, s. 35-43.

${ }^{64}$ M.G. Haviland i in., Alexithymia in women and men hospitalized for psychoactive substance dependence, Comprehensive Psychiatry, 1994, 35, s. 124-1284; E. Zdankiewicz-Ścigała, Aleksytymia i dysocjacja, jako podstawowe czynniki zjawisk potraumatycznych, Warszawa 2017. 
Wnioskiem płynącym dla praktyki społecznej z przeprowadzonych badań jest oferta interwencji psychoedukacyjnych i terapeutycznych, które mogą być przeprowadzane $\mathrm{w}$ obszarze przetwarzania emocjonalnego dla wychowanków rodzin zastępczych ${ }^{65}$. Inicjatywy o takim charakterze są z powodzeniem podejmowane między innymi na gruncie terapii poznawczo-behawioralnej ${ }^{66}$. Uzyskane dane pokazują, iż terapia mająca pierwotnie na celu osłabianie zaburzeń psychicznych poprzez proces poznawczy, usprawnia także przetwarzanie emocjonalne. Wszelkie działania o charakterze psychokorekcyjnym skoncentrowane na emocjach mogą przyczynić się do obniżenia deficytów przewarzania emocjonalnego i stosowania przez wychowanków rodzin zastępczych efektywniejszych strategii regulacji emocji (np. terapia ukierunkowana na schematy emocjonalne ${ }^{67}$ ). Takie oddziaływania w przypadku osób podejmujących samodzielne życie, poza pieczą zastępczą, może być niezwykle przydatne z racji wyzwań, jakie przed nimi stoją ${ }^{68}$.

Słabą stroną zastosowanej procedury badawczej jest niewielka liczebność badanej grupy. Ponadto, uzyskane wyniki dotyczące lingwistycznej reprezentacji emocji mogą mieć charakter pozorny, ponieważ nie kontrolowano inteligencji werbalnej uczestników, która może być w silnym związku z omawianą zmienną. W przyszłych badaniach dotyczących dyskutowanej problematyki należy wprowadzić takie metody, które pozwolą na badanie indywidualnych trajektorii rozwojowych wychowanków rodzin zastępczych i będą obejmowały między innymi informację o długości przebywania w rodzinie zastępczej, czy typie rodziny zastępczej. Wśród modyfikacji warsztatowych warto byłoby wprowadzić metody o charakterze autobiograficznym, dzięki którym można by na przykład szacować symptomatologię aleksytymii wtórnej w odniesieniu do wczesnodziecięcych doświadczeń.

Pani dr Karolinie Rajewskiej-Rynkowskiej składamy serdeczne podziękowania za udostępnienie polskiej adaptacji Experiences in Close Relationships Scale i obszernych fragmentów swojej pracy doktorskiej, jak równeż mgr Nadii Kostrzewie za przeprowadzenie przedstawionych $\mathrm{w}$ artykule badań i zgodę na ich publikację.

${ }^{65}$ R. Baker i in., Emotional Processing Therapy for Post Traumatic Stress Disorder, Counselling Psychology Quarterly, 2013, 26, s. 362-385.

${ }^{66}$ R. Baker i in., Does CBT facilitate emotional processing? Behavioural and Cognitive Psychotherapy, 2012, 40, s. 19-37; por. B. Górecka-Mostowicz, Wspomaganie poznawczej reprezentacji emocji u dzieci przedszkolnych i szkolnych - refleksje i propozycje, [w:] Nauki pedagogiczne w teorii i praktyce, red. J. Kuźma, J. Morbitzer, Kraków 2003, s. 140-149.

${ }^{67}$ R.L. Leahy, A model of emotional schemas, Cognitive and Behavioral Practice, 2002, 9, 3, s. 177-190; R.L. Leahy, D. Tirch, L.A. Napolitano, Regulacja emocji w psychoterapii, Kraków 2014.

${ }^{68}$ S. Kools, C. Kennedy, Foster child health and development: Implications for primary care, Pediatric Nursing, 2003, 29, 1, s. 39-45. 


\section{BIBLIOGRAFIA}

Bagby J.D., Taylor G.J., Affect dysregulation and alexithymia, [w:] Disorders of affect regulation; alexithymia in medical and psychiatric illness, red. G.J. Taylor, R.M. Bagby, J.D.A Parker, Cambridge University Press, Cambridge 1997.

Bagby J.D., Taylor G.J., Anxiety and depressive disorders and a note on personality disorders, [w:] Disorders of affect regulation; alexithymia in medical and psychiatric illness, red. G.J. Taylor, R.M. Bagby, J.D.A Parker, Cambridge University Press, Cambridge 1997.

Baker R., Gale L., Abbey G., Thomas S., Emotional Processing Therapy for Post Traumatic Stress Disorder, Counselling Psychology Quarterly, 2013, 26.

Baker R., Holloway J., Thomas P.W., Thomas S., Owens M., Emotional processing in panic, Behaviour Research and Therapy, 2004, 42.

Baker R., Thomas S., Thomas P.W., Owens M., Development of an emotional processing scale, Journal of Psychosomatic Research, 2007, 62.

Baker R., Thomas S., Thomas P.W., Gower P., Whittlesea A., Emotional Processing Research. Information booklet - materiał niepublikowany, 2007.

Baker R. i in., Does CBT facilitate emotional processing? Behavioural and Cognitive Psychotherapy, 2012, 40.

Bartholomew K., Horowitz L.M., Attachment Styles among Young Adults: A Test of a FourCategory Model, Journal of Personality and Social Psychology, 1991, 61.

Bilikiewicz A., Strzyżewski W., Psychiatria: podręcznik dla studentów medycyny, PZWL, Warszawa 1992.

Bowlby J., Attachment and Loss, vol. 1, Penguin Books, Harmondsworth 1982.

Bowlby J., Attachment and Loss. Loss: Sadness and Depression, vol. 3, Penguin Books, Harmondsworth 1991.

Brennan K.A., Clark C.L., Shaver P.R., Self-Report Measurement of Adult-Attachment. An Integrative Overview, [w:] Attachment Theory and Close Relationships, red. J.A. Simpson, W.S. Rholes, Guilford Press, New York 1998.

Bretherton I., Munholland K.A., Internal Working in Attachment Relationships. A Construct Revisited [w:] Handbook of Attachment. Theory. Research and Clinical Applications, red. J. Cassidy, P.R. Shaver, The Guilford Press, New York - London 1999.

Bridges L.J., Grolnick W.S., Connell J.P., Infant emotion regulation with mothers and fathers, Infant Behavior and Development, 1997, 20.

Bruskas D., Care: A Vulnerable Population at Risk, Journal of Child and Adolescent Psychiatric Nursing, 2008, 21.

Brzeziński R., Dwie dekady koncepcji aleksytymii, Psychiatria Polska, 1995, 29.

Bucci W., The Need for a "Psychoanalytic Psychology" in the Cognitive Science Field, Psychoanalytic Psychology, 2000, 17.

Bucci W., The interplay of subsymbolic and symbolic processes in psychoanalytic treatment, Psychoanalytic Dialogues, 2005, 15, 6.

Courtney M.E., Piliavin I., Grogan K., Nesmith A., Foster youth transitions to adulthood: A longitudinal view of youthleaving care, Child Welfare, 2001, 80.

Czub M., Wiek niemowlęcy. Jak rozpoznać potencjat dziecka? [w:] Psychologiczne portrety człowieka. Praktyczna psychologia rozwojowa, red. A.I. Brzezińska, GWP, Gdańsk 2005.

Dunn J., Creps C., Brown J., Children's family relationships between two and five: Developmental changes and individual differences, Social Development, 1996, 3.

Edelstein R.S., Ghetti S., Quas J.A., Goodman G.S., Alexander K.W., Redlich A.D., Cordón I.M., Individual differences in emotional memory: Adult attachment and long-term memory for child sexual abuse, Personality and Social Psychology Bulletin, 2005, 31. 
Eng W., Heimberg R.G., Hart T.A., Schneier F.R., Liebowitz M.R., Attachment in individuals with social anxiety disorder: The relationship among adult attachment styles, social anxiety, and depression, Emotion, 2001, 1, 4.

Frawley W., Smith R.N., A processing theory of alexithymia, Cognitive Systems Researc, 2001, 22.

Freyberger H., Supportive psychotherapeutic techniques in primary and secondary alexithymia, Psychotherapy and Psychosomatics, 1977, 28.

Fuendeling J.M., Affect Regulation as a Stylistic Process within Adult Attachment, Journal of Social and Personal Relationships, 1998, 15, 3.

Górska D., Jasielska A., Konceptualizacja przetwarzania emocjonalnego i jego pomiar - badania nad polska wersją Skali Przetwarzania Emocjonalnego Bakera i wspótpracowników, Studia Psychologiczne, 2010, 48, 3.

Górecka-Mostowicz B., Wspomaganie poznawczej reprezentacji emocji u dzieci przedszkolnych i szkolnych - refleksje i propozycje, [w:] Nauki pedagogiczne w teorii i praktyce, red. J. Kuźma, J. Morbitzer, Wydawnictwo Naukowe UP, Kraków 2003.

Gross J.J. (red.), Handbook of emotion regulation, Guilford Press, New York 2007.

Haviland M.G., Hendryx S., Shaw D.G., Henry J.P., Alexithymia in women and men hospitalized for psychoactive substance dependence, Comprehensive Psychiatry, 1994, 35, s.1241284 .

Hazan C., Zeifman D., Pair Bonds as Attachments: Evaluating the Evidence, [w:] Handbook of Attachment. Theory. Research and Clinical Applications, red. J. Cassidy, P.R. Shaver, The Guilford Press, New York - London 1999.

Honkalampi K., Hintikka J., Tanskanen A., Lehtonen J., Viinamaki H., Depression is strongly associated with alexithymia in the general population, Journal of Psychosomatic Research, 2000,48 .

Jasielska A., Zastosowanie analizy transkrypcji do pomiaru inteligencji emocjonalnej, Psychologia. Edukacja i Społeczeństwo, 2007, 4, 1.

Jasielska A., Zglenicka A., Styl przywiazania $i$ deficyty przetwarzania emocjonalnego $u$ ofiar przemocy domowej, II Krajowa Konferencja Psychologii Klinicznej „Oblicza integracji w obszarach teorii i praktyki psychologii klinicznej, 24-26 listopada 2016, Poznań 2016.

Kench S., Irwin. H.J., Alexithymia and childhood family environment, Journal of Clinical Psychology, 2000, 5 .

Kochanska G., Coy. K.C., Child emotionality and maternal responsiveness as predictors of reunion behaviors in the strange situation: Links mediated and inmediated by separation distress, Child Development, 2002, 73.

Kools S., Kennedy C., Foster child health and development: Implications for primary care, Pediatric Nursing, 2003, 29, 1.

Kostrzewa N., Rola $i$ znaczenie więzi przywiazaniowej w funkcjonowaniu emocjonalnym osób dorostych - niepublikowana praca magisterska, Instytut Psychologii UAM, Poznań 2011.

Krystal H., Integration and self-healing: affect, trauma, alexithymia, Hillsdale, Analytic Press, New York 1988.

Kryteria Diagnostyczne z DSM-5. Desk Reference, Edra Urban \&Partner, Wrocław 2015.

Leahy R.L., A model of emotional schemas, Cognitive and Behavioral Practice, 2002, 9, 3.

Leahy R.L., Tirch D., Napolitano L.A., Regulacja emocji w psychoterapii, Wydawnictwo UJ, Kraków 2014.

Liciński M., Rodzina zastępcza dla dzieci bez przyszłości, Problemy Opiekuńczo-Wychowawcze, 2009, 5 .

Marczewski E. (red.), Stownik terminów nauki o języku, WSiP, Warszawa 1985. 
Maruszewski T., Ścigała E., Emocje - aleksytymia - poznanie, Wydawnictwo Humaniora, Poznań 1998.

Mickiewicz K., Funkcjonowanie rodzinnej pieczy zastępczej. Problematyka psychologiczna, [w:] Administracja opiekuńcza, red. M. Szreniawska, Wydawnictwo WSPA, Lublin 2015.

Mikulincer M., Adult Attachment Style and Affect Regulation: Strategic Variations in Self-Appraisals, Journal of Personality and Social Psychology, 1998, 75, 2.

Mikulincer M., Florian V., Exploring Individual Differences in Reactions to Mortality Salience: Does Attachment Style Regulate Terror Management Mechanisms? Journal of Personality and Social Psychology, 2000, 79, 2.

Mikulincer M., Shaver P.R., Pereg D., Attachment Theory and Affect Regulation: The Dynamics. Development. and Cognitive Consequences of Attachment-Related Strategies, Motivation and Emotion, 2003, 27, 2.

Nowak M., Gawęda A., Janas-Kozik M., Prowokacja odrzucenia czy pragnienie bliskości. Znaczenie relacji rodzic zastępczy-dziecko dla niwelowania deficytów wynikających z diagnozy „zabrudzenie więzi”, Psychiatra i Psychologia Kliniczna, 2011, 11.

Okoń W., Nowy stownik pedagogiczny, Wydawnictwo Akademickie Żak, Warszawa 2001.

Parker J.D.A, Taylor G.J., Relations beteen alexithymia. Personality, and affects, [w:] Disorders of affect regulation; alexithymia in medical and psychiatric illness, red. G.J. Taylor, R.M. Bagby, J.D.A Parker, Cambridge University Press, Cambridge 1997.

Płońska D., Czernikiewicz A., Aleksytymia - ciągle wiele pytań, część I - Definiowanie aleksytymii, Psychiatria, 2006, 3.

Rachman S., Emotional processing, Behaviour Research and Therapy, 1980, 18.

Rachman S., Emotional processing with special reference to posttraumatic stress disorder, International Review of Psychiatry, 2001, 13.

Rajewska-Rynkowska K., Schematy przywiązania do obiektu religijnego w kontekście aktywacji myśli o śmierci - niepublikowana praca doktorska, Instytut Psychologii UAM, Poznań 2008.

Ruszkowska M., Diagnoza rodzin zastępczych w obliczu dylematów wspótczesności, Centrum Rozwoju Zasobów Ludzkich, Warszawa 2013.

Ruszkowska M., Rodzina zastępcza jako środowisko opiekuńczo-wychowawcze, Centrum Rozwoju Zasobów Ludzkich, Warszawa 2013.

Semin G.R., Görts C.A., Nandram S., Semin-Goossens A., Cultural perspectives on the linguistic representation of emotion and emotion events, Cognition and Emotion, 2002, 16, 1.

Taylor G.J., Bagby R.M., Parker J.D.A., The development and regulation of affect, [w:] Disorders of affect regulation; alexithymia in medical and psychiatric illness, red. G.J. Taylor, R.M. Bagby, J.D.A Parker, Cambridge University Press, Cambridge 1997.

Telka L., Sytuacja dziecka wychowywanego poza rodzina wtasna - analiza wybranych badań, [w:] Zagrożone dziecinstwo. Rodzinne i instytucjonalne formy opieki, red. M. Kolankiewicz, WSiP, Warszawa 1998.

Tomalski R., Aleksytymia i dysocjacja, Psychoterapia, 2008, 2, 145.

Troisi A., D'argenio A., Peracchio F., Petti P., Insecure attachment and alexithymia in young men with mood symptoms, Journal of Nervous and Mental Disease, 2001, 189.

Waters E., Weinfield N.S., Hamilton C.E., The Stability of Attachment Security from Infancy to Adolescence and Early Adulthood: General Discussion, Child Development, 2000, 71, 3.

Weinfield N.S., Sroufe L.A., Egeland B., Attachment from Infancy to Early Adulthood in a High-Risk Sample: Continuity, Discontinuity, and Their Correlates, Child Development, 2000, 71,3 .

Zdankiewicz-Ścigała E., Aleksytymia i dysocjacja, jako podstawowe czynniki zjawisk potraumatycznych, Wydawnictwo Naukowe Scholar, Warszawa 2017. 